Bangladesh J. Plant Taxon. 21(1): 43-51, 2014 (June)

(C) 2014 Bangladesh Association of Plant Taxonomists

\title{
STOMATAL AND TRICHOME DIVERSITY IN SENNA MILL. FROM BANGLADESH
}

\author{
Ayesa Begum, Md. Oliur Rahman ${ }^{1}$ and Momtaz Begum \\ Department of Botany, University of Dhaka, Dhaka 1000, Bangladesh
}

Keywords: Senna; Stomata; Trichomes; Taxonomy; Bangladesh.

\begin{abstract}
Foliar epidermal characters of ten species of Senna Mill. found in Bangladesh are investigated. Anisocytic, anomocytic, paracytic, tetracytic and haxacytic stomata are found across the species. Anisocytic and paracytic stomata are common in all species. In addition to anisocytic and paracytic types, anomocytic stomata are found in Senna sophera and hexacytic stomata are observed in S. auriculata. Anticlinal wall is straight in S. alata, S. hirsuta, S. occidentalis, S. siamea and S. tora, curved in S. auriculata, $S$. sophera and $S$. siamea, and undulate in $S$. hirsuta and S. occidentalis. Glandular trichomes are observed in S. hirsuta and $S$. occidentalis, while non-gladular trichomes are predominant in the remaining species.
\end{abstract}

\section{Introduction}

Senna Mill. is a large, widespread genus and exhibits a high diversity of habits including herbs, shrubs, treelets, tall trees and lianas. The genus comprises 350 species and about $80 \%$ of its species occur in the American continent, while most of the remaining members are found in tropical Africa, Madagascar and Australia, and only a few species occur in South-eastern Asia and Pacific Island (Irwin and Barneby, 1982; Marazzi et al., 2006). Species of Senna were formerly included in Cassia L. s.l. (Irwin and Turner, 1960). Subsequent taxonomic treatments subdivided the Cassia s.l. into three distinct genera, viz., Cassia s. str., Chamaecrista Moench and Senna Mill. (Irwin and Barneby, 1981, 1982). Senna Mill. are characterized by presence of extrafloral nectaries, ebracteolate pedicels, straight or simply incurved filaments, flattened or cylindrical, irregularly dehiscent pods and areolate seeds, while in Cassia L., no extrafloral nectaries present, pedicels 2-bracteolate, filaments sigmoidally curved towards the base, pod indehiscent, and there is no areole on seed surface. Chamaecrista Moench is distinct by ciliolate anther-thecae along the suture, elastically dehiscent pod, smooth or pitted seed coat and absence of aerole on seed surface (Irwin and Barneby, 1982). The separation of Senna Mill. from Cassia L. was further established by taxonomic (Singh, 2001), phenetic (Boonkerd et al., 2005) and molecular studies (Acharya et al., 2011). In Bangladesh, Senna Mill. is represented by 11 species (Rahman et al., 2013).

Taxonomic relevance of vegetative anatomy in delimitation of taxa and establishment of itergeneric or interspecific relationships is well reported (Tomblinson, 1961; Stace, 1965; Kotresha and Seetharam, 2000; Tschan and Denk, 2012). Foliar anatomical features play an important role in distinguishing different groups of plants. Leaf is considered as the most varied organ anatomically in angiosperms which provides a variety of anatomical features that can be employed as useful taxonomic characters (Metcalfe and Chalk, 1950; Metcalfe, 1968; Stace, 1984). Foliar anatomical characters such as stomata and trichomes have been found instrumental in solving taxonomic problems. The taxonomic and phylogenetic significance of stomata and trichomes have long been recognized by various workers (Dilcher, 1974; Naik and Nirgude, 1981; Stace, 1984; Devi et al., 2013).

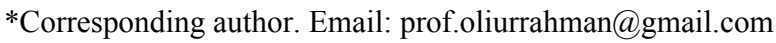


Despite several studies based on foliar micromorphology have been made in defferent genera, viz., Polygonum (Lersten and Curtis, 1992), Eugenia (Fontenelle et al., 1994), Bauhinia (Kotresha and Seetharam, 1995), Hibiscus (Shaheen et al., 2009), Fagopyrum (Yasmin et al., 2010) and Cynoglossum (Akçin et al., 2012), the genus Senna Mill. received very little attention in this regard (Ogundipe et al., 2009). Therefore the present study was undertaken in order to explore the features of stomata and trichome in the genus Senna Mill. occurring in Bangladesh and to evaluate these characters for species delimitation and interspecific relationship.

\section{Materials and Methods}

Ten species of Senna Mill. used in this study are Senna alata (L.) Roxb., S. auriculata (L.) Roxb., S. hirsuta (L.) Irwin \& Barneby, S. obtusifolia (L.) Irwin \& Barneby, S. occidentalis (L.) Link, S. siamea (Lam.) Irwin \& Barneby, S. sophera (L.) Roxb., S. surattensis (Burm. f.) Irwin \& Barneby, S. timoriensis (DC.) Irwin \& Barneby and S. tora (L.) Roxb. The localities of these species along with the voucher numbers are appended in Table 1. Plant materials collected from different parts of the country as well as herbarium specimens deposited in Dhaka University Salar Khan Herbarium (DUSH) and Bangladesh National Herbarium (DACB) were studied.

Leaf samples were cut into small square pieces and soaked in a petridish containing $\mathrm{KOH}$ solution for 7-8 days. Then they were washed with tap water followed by treatment with hydrogen peroxide for 3-4 days till clearing of leaves. After that they were treated with $50 \%$ alcohol for 2 hours and then with safranin for 16-18 hours. The leaf tissues were treated again with $70 \%$ alcohol for 2 hours. Finally, the samples were treated with a mixture of alcohol and xylol in a 3:1 ratio and mounted in $70 \%$ glycerin. The samples were prepared in clean, dry and oil free slides and observed under compound microscope. Photomicrograph of each species was taken using Nikon Eclipse 200 camera in addition to the line drawing of stomata.

Table 1. List of species of Senna Mill. along with voucher specimens used in the present study.

\begin{tabular}{|c|c|c|}
\hline No. & Species & Voucher specimens \\
\hline 1 & Senna alata (L.) Roxb. & $\begin{array}{l}\text { Dhaka: Dhaka University campus, 23.12.2011, Ayesa } 65 \\
\text { (DUSH) }\end{array}$ \\
\hline 2 & S. auriculata (L.) Roxb. & $\begin{array}{l}\text { Dhaka: Sher-e-Bangla Agricultural University compound, } \\
\text { 26.1.2011, Ayesa } 07 \text { (DUSH) }\end{array}$ \\
\hline 3 & S. hirsuta (L.) Irwin \& Barneby & Gazipur: Gazipur, 30.6.2011, Ayesa 40 (DACB) \\
\hline 4 & S. obtusifolia (L.) Irwin \& Barneby & $\begin{array}{l}\text { Cox’s Bazar: Teknaf, Mouchuni, 24.4.2011, Ayesa } 32 \\
\text { (DUSH) }\end{array}$ \\
\hline 5 & S. occidentalis (L.) Link & $\begin{array}{l}\text { Dhaka: Dhaka University campus, 26.12.2010, Ayesa } 02 \\
\text { (DUSH) }\end{array}$ \\
\hline 6 & S. siamea (Lam.) Irwin \& Barneby & $\begin{array}{l}\text { Dhaka: Tejgaon, Old Airport, 27.12.2011, Ayesa } 74 \\
\text { (DUSH) }\end{array}$ \\
\hline 7 & S. sophera (L.) Roxb. & $\begin{array}{l}\text { Dhaka: Dhaka University Campus, 30.4.11, Aeysa } 33 \\
\text { (DUSH) }\end{array}$ \\
\hline 8 & $\begin{array}{l}\text { S. surattensis (Burm. f.) Irwin \& } \\
\text { Barneby }\end{array}$ & $\begin{array}{l}\text { Dhaka: Dhaka University campus, 20.12.2011, Ayesa } 47 \\
\text { (DUSH) }\end{array}$ \\
\hline 9 & S. timoriensis (DC.) Irwin \& Barneby & $\begin{array}{l}\text { Chittagong Hill Tracts: Ruma P.S., Changnakra, } \\
\text { 25.1.1965, M. S. Khan } 1166 \text { (DACB). }\end{array}$ \\
\hline 10 & S. tora (L.) Roxb. & $\begin{array}{l}\text { Dhaka: Dhaka University Botanical garden, 26.12.2011, } \\
\text { Ayesa } 69 \text { (DUSH) }\end{array}$ \\
\hline
\end{tabular}




\section{Results and Discussion}

The genus Senna offers different types of stomata and trichomes. The shape of epidermal cells, nature of anticlinal walls, types of stomata and number of stomata per microscopic field are presented in Table 2. The epidermal cells are irregular or polygonal in outline. Polygonal cells are observed in S. obtusifolia, S. siamea and S. tora, while irregular types of cells are evident in $S$. sophera. The remaining species bear both irregular and polygonal cells (Table 2). The anticlinal walls are straight, undulate and curved across the genus. Straight anclinal walls are found in $S$. obtusifolia, S. siamea and S. tora; anticlinal walls are curved in S. auriculata, S. sophera and S. surattensis, and they are undulate, curved and straight in S. hirsuta and S. occidentalis. Stomata are mostly paracytic and anisocytic, however, tetracytic, anomocytic and hexacytic stomata have also been documented. Paracytic and anisocytic stomata are observed in all species, while anomocytic stomata are found only in S. sophera, and hexacytic stomata only in S. auriculata along with other types. Paired anisocytic and paired tetracytic stomata are present only in $S$. auriculata. Paired paracytic stomata are observed in S. sophera and S. hirsuta (Table 2; Figs 1\&2). Amphistomatic stomata have been observed in all species employed, while hypostomatic stomata is found only in S. siamea.

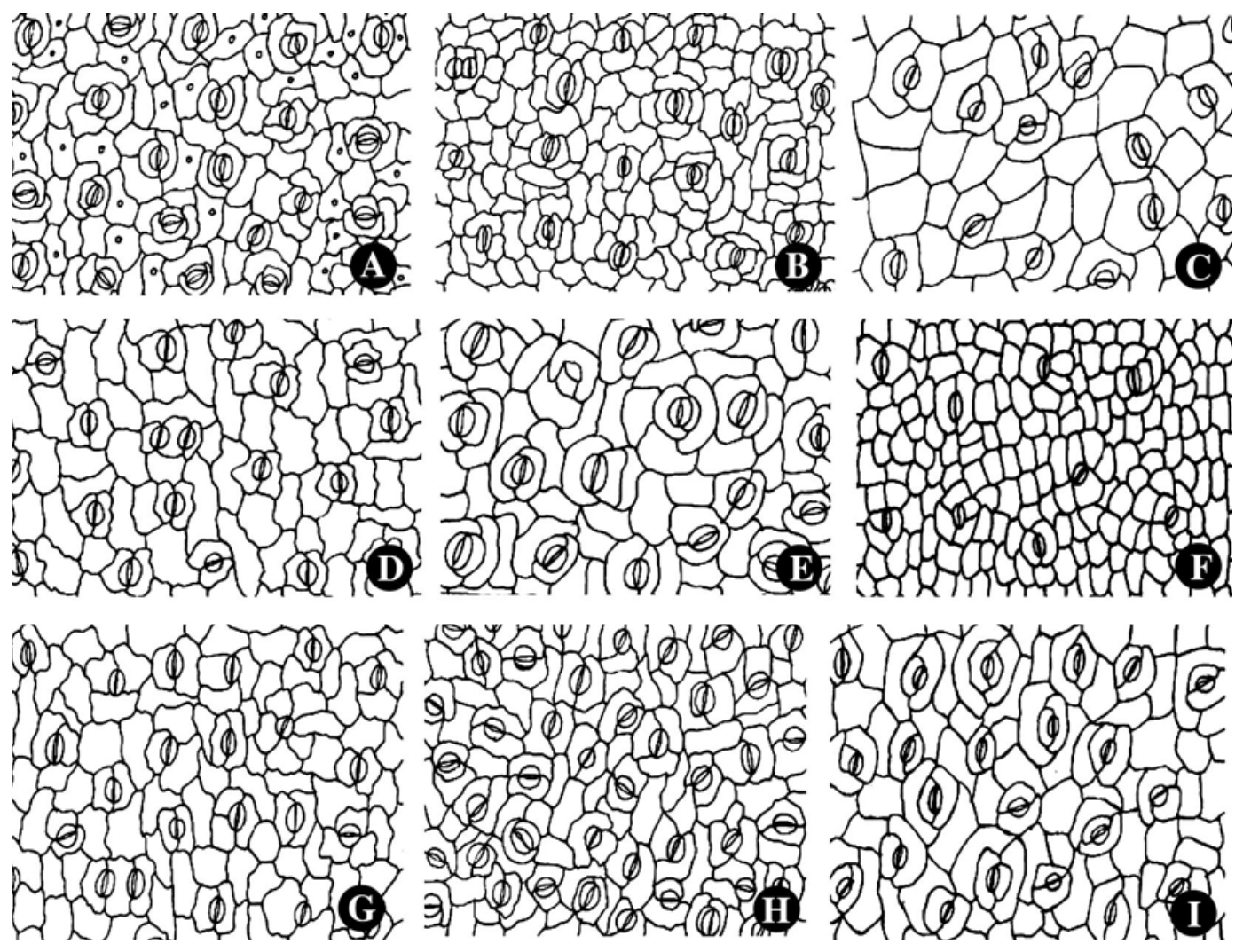

Fig. 1. Line drawings of different types of stomata found in Senna Mill., A) Senna alata, B) S. auriculata, C) S. hirsuta, D) S. obtusifolia, E) S. occidentalis, F) S. siamea, G) S. sophera, H) S. surattensis, I) S.tora. 


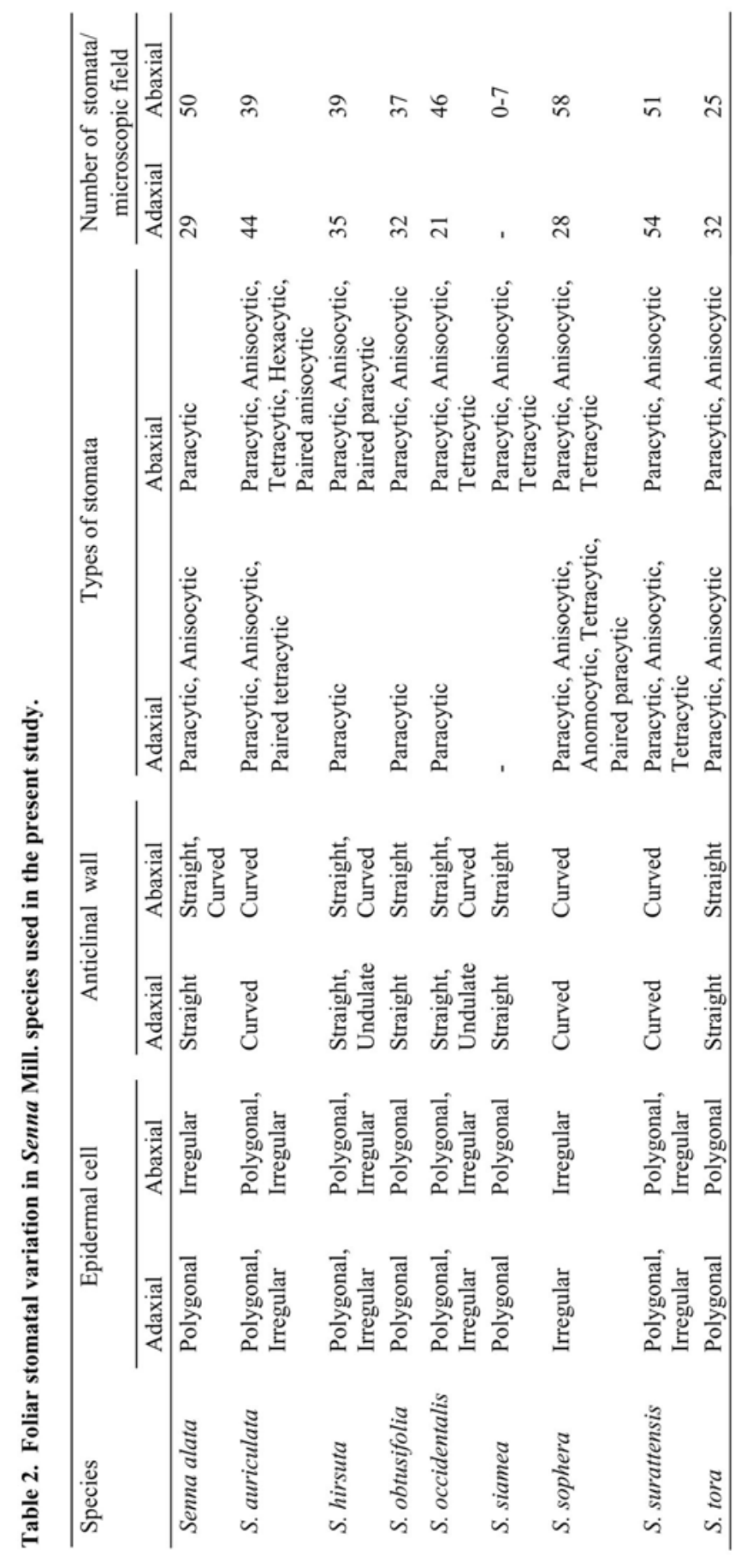



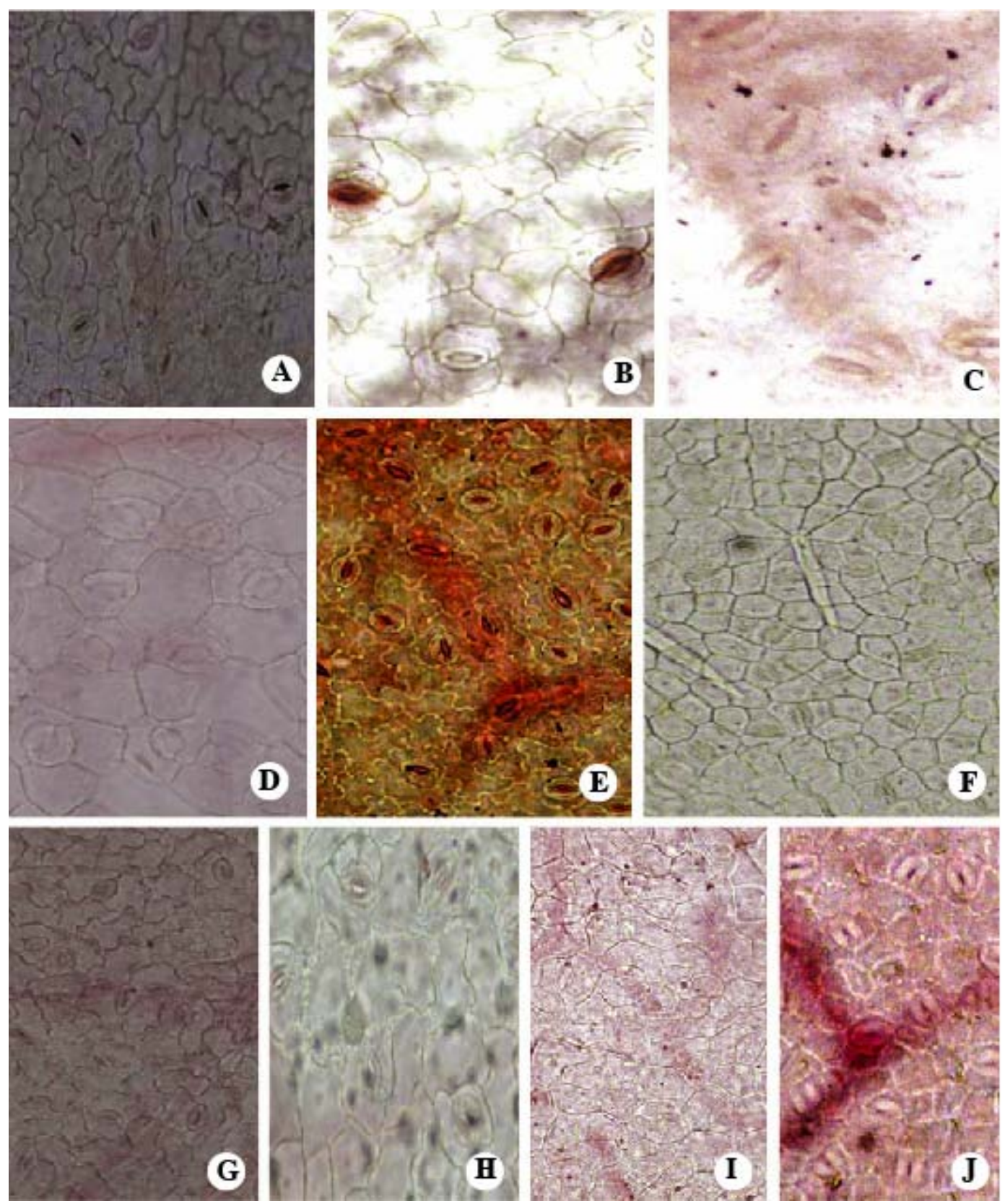

Fig. 2. Different types of stomata in Senna Mill. A) Senna alata, B) S. auriculata, C) S. hirsuta, D) S. obtusifolia, E) S. occidentalis, F) S. siamea, G) S. sophera, H) S. surattensis, I) S. tora, J) S. timoriensis.

The study reveals that both glandular and non-glandular trichomes are found in Senna. The trichomes observed in Senna vary in structure, form and distribution. Glandular multicellular trichomes are evident only in the abaxial surface of S. hirsuta and S. occidentalis. The number of 
cells varies from 5 to 7 . However, no glandular unicellular trichomes are found in any species employed in the present study (Table 3). Non-glandular trichomes are evident in all species except S. occidentalis. Non-glandular multicellular trichomes are distinct in S. hirsuta, S. obtusifolia and S. tora, whereas, non-glandular unicellular trichomes are observed in eight species. In S. alata, S. hirsuta and S. siamea unicellular trichomes are sparsely noticed. Non-glandular unicellular trichomes may be conical or papilose. Very rarely uncinate trichomes are found only in S. alata. Non-glandular multicellular trichomes are consisted of 2-8 cells, which also vary greatly in size, shape and number of cells.Verrucose type of trichome wall are documented in S. tora, $S$. obtusifolia, S. siamea, S. surattensis and smooth walled trichomes are seen in S. hirsuta, S. auriculata, S. timoriensis (Fig. 3). The longest type of multicellular trichomes are present with up to 8 cells, comprising two or more basal cells ended by a much elongated apical cell in S. hirsuta. The pedastal cells might vary from 4 to 7 . Multicellular verrucose trichome present in S. tora and S. obtusifolia. The cells of the stalk are almost equal in length. Smooth walled non-glandular multicellular trichomes are present in S. hirsuta, consisting of 2-6 cells and the cells may be equal or unequal in size. The upper cells always larger than the basal ones and become narrower towards the apex. S. occidentalis and S. hirsuta can easily be distinguished from the other species of Senna by presence of glandular multicellular trichomes.

Table 3. Trichome variation in Senna Mill. species employed in the present study.

\begin{tabular}{|c|c|c|c|c|c|c|c|c|}
\hline \multirow{3}{*}{ Species } & \multicolumn{4}{|c|}{ Glandular trichome } & \multicolumn{4}{|c|}{ Non-glandular trichome } \\
\hline & \multicolumn{2}{|c|}{ Unicellular } & \multicolumn{2}{|c|}{ Multicellular } & \multicolumn{2}{|c|}{ Unicellular } & \multicolumn{2}{|c|}{ Multicellular } \\
\hline & $\begin{array}{l}\text { Adaxial } \\
\text { surface }\end{array}$ & $\begin{array}{l}\text { Abaxial } \\
\text { surface }\end{array}$ & $\begin{array}{l}\text { Adaxial } \\
\text { surface }\end{array}$ & $\begin{array}{l}\text { Abaxial } \\
\text { surface }\end{array}$ & $\begin{array}{l}\text { Adaxial } \\
\text { surface }\end{array}$ & $\begin{array}{l}\text { Abaxial } \\
\text { surface }\end{array}$ & $\begin{array}{l}\text { Adaxial } \\
\text { surface }\end{array}$ & $\begin{array}{l}\text { Abaxial } \\
\text { surface }\end{array}$ \\
\hline Senna alata & - & - & - & - & $\begin{array}{l}+ \text { (very } \\
\text { few) }\end{array}$ & $\begin{array}{l}+(\text { very } \\
\text { few) }\end{array}$ & - & - \\
\hline S. auriculata & - & - & - & - & ++ & ++ & - & - \\
\hline S. hirsuta & - & - & - & $\begin{array}{l}+ \text { (very } \\
\text { few) }\end{array}$ & - & $\begin{array}{l}+(\text { very } \\
\text { few) }\end{array}$ & $\begin{array}{l}+++(2-6 \\
\text { celled })\end{array}$ & $\begin{array}{l}+++(2-4 \\
\text { celled })\end{array}$ \\
\hline S. obtusifolia & - & - & - & - & ++ & - & - & $\begin{array}{l}++(1-7 \\
\text { celled })\end{array}$ \\
\hline S. occidentalis & - & - & - & $\begin{array}{l}++(5-7 \\
\text { celled })\end{array}$ & - & - & - & - \\
\hline S. siamea & - & - & - & - & $\begin{array}{l}+(\text { very } \\
\text { few) }\end{array}$ & $\begin{array}{l}+(\text { very } \\
\text { few) }\end{array}$ & - & - \\
\hline S. sophera & - & - & - & - & ++ & ++ & - & - \\
\hline S. surattensis & - & - & - & - & ++ & ++ & - & - \\
\hline S. timoriensis & - & - & - & - & ++ & +++ & - & - \\
\hline S. tora & - & - & - & - & - & - & - & $\begin{array}{l}++(2-4 \\
\text { celled })\end{array}$ \\
\hline
\end{tabular}

$-=$ absent,$+=$ sparsely present,$++=$ moderately present,$+++=$ densely present.

The taxonomic value of leaf epidermal characters have been received much attention in the recent past, even the taxonomic monographs are now considered incomplete without micromorphology of the epidermis (Rejdali, 1991). In this context, however, little is known in the genus Senna. Recently Ogundipe et al. (2009) and Shaheed and Illoh (2010) studied foliar micromorphology of six species of Senna from Nigeria. The present study bridges the gaps in our knowledge of the some additional species of the genus Senna after Ogundipe et al. (2009) and Shaheed and Illoh (2010). 

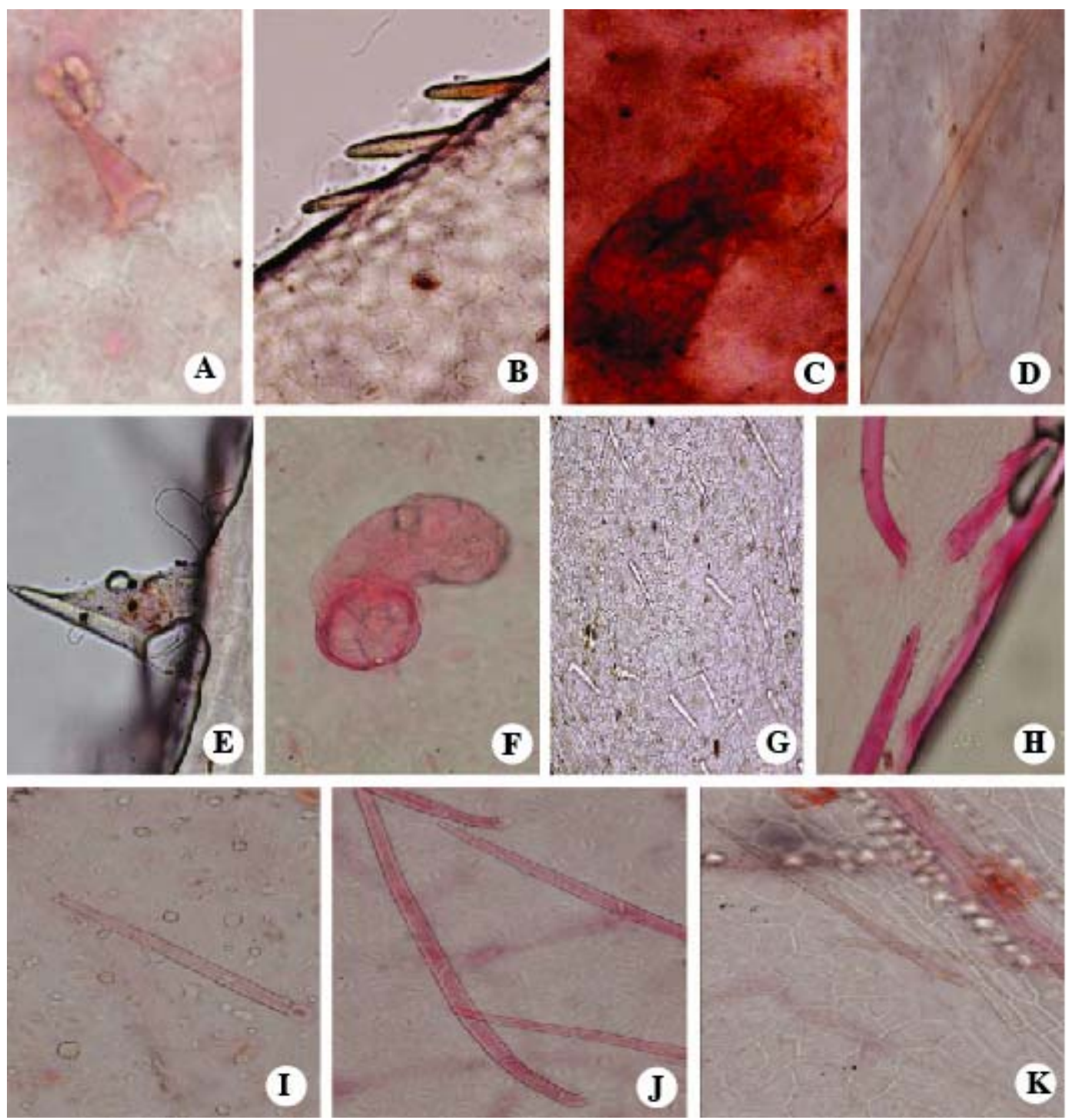

Fig. 3. Trichome diversity in Senna Mill., A) Senna alata, B) S. auriculata, C,D) S. hirsuta, E) S. obtusifolia, F) S. occidentalis, G) S. siamea, H) S. sophera, I) S. surattensis, J) S. tora., K) S. timoriensis.

The present study reveals that the foliar epidermal characters are important in taxonomic identification and species relationships in the members of the Senna examined. In our study $S$. obtusifolia and S. tora have been found closely related as evidenced by their epidermal cells which are polygonal in shape, and anticlinal walls are straight both in S. obtusifolia and S. tora. Moreover, paracytic and anisocytic stomata are common in these two species indicating a close relationships among them. In a morphometric study of the genus Senna Rahman et al. (2013) showed that $S$. obtusifolia and S. tora are very closely related as attested by the following shared characters: leaflets obovate, stipules linear, falcate, inflorescence short-racemose, axillary, ovary ribbed, style glabrous, stigma truncate and pod linear or subtetragonous, which has been found 
consitent with our study. Morphologically S. alata and S. auriculata are closely allied, however, the epidermal features do not support a close association between them. S. auriculata is characterized by presence of hexacytic stomata, while S. sophera is distinct by presence of anomocytic stomata. Saheed and Illoh (2010) observed that in S. alata, the adaxial epidermal cells are polygonal or irregular, while the abaxial cells are irregular in shape, and this species exhibited non-glandular trichomes. Our study presenting similar types of epidermal cells and non-glandular trichomes in S. alata support the work of Saheed and Illoh (2010). S. obtusifolia is characterized by presence of polygonal epidermal cells, straight anticlinal walls, and paracytic and anisocytic stomata, however, no anomocytic stomata were found in this species as documented by Saheed and Illoh (2010).

The study also unveils a close relationship between S. hirsuta and S. occidentalis as they share the following common characteristics: both polygonal and irregular epidermal cells, straight and undulate anticlinal walls in the adaxial surface, straight and curved walls in the abaxial surface, paracytic stomata in the adaxial surface, and both paracytic and anisocytic stomata in the abaxial surface (Table 2). S. hirsuta and S. occidentalis can also be differentiated from the remaining species by presence of multicellular glandular trichomes as observed in the abaxial surface (Table 3). While studying on the Nigerian Senna species Ogundipe et al. (2009) showed that S. hirsuta and S. occidentalis are closely allied as they bear paracytic and anisocytic types of stomata, and the epidermal cells are polygonal and irregular in both species. Results obtained from the present study have been found congruent with that of Ogundipe et al. (2009). The close affinity between S. hirsuta and S. occidentalis is also evidenced by cytological investigation where the somatic chromosome number $2 \mathrm{n}=28$ was reported for these species (Bir and Kumari, 1980).

\section{Acknowledgement}

We would like to thank Prof. Dr. Md. Abul Hassan, Department of Botany, University of Dhaka for his cooperartion during the course of the study. Thanks are also due to the authority of Bangladesh National Herbarium for allowing us to examine the herbarium materials.

\section{References}

Acharya, L., Mukherjee, A.K. and Panda, P.C. 2011. Separation of the genera in the subtribe Cassiinae (Leguminosae: Caesalpinioidae) using molecular markers. Acta Botanica Brasilica 25(1): 223-233.

Akçin, O.E., Çoşkunçelebi, K. and Şenel, G. 2012. Foliar anatomy of Cynoglossum L. (Boraginaceae) from north Anatolia, Turkey. Bangladesh J. Plant Taxon. 19(2): 101-108.

Bir, S.S. and Kumari, S. 1980. Cytological evolution of the Leguminous flora of the Punjub plain. In: Bir, S.S. (Ed.), Recent Researches in Plant Science. Kalyani Publishers, Ludhiana, India, pp. 261-271.

Boonkerd, T., Pechsri, S. and Baum, B.R. 2005. A phenetic study of Cassia s.l. (LeguminosaeCaesalpinioideae: Cassieae: Cassiinae) in Thailand. Plant Syst. Evol. 252: 153-165.

Devi, N.J., Padma, Y., Narasimhudu, C.L. and Raju, R.R.V. 2013. Diversity of stomata and trichomes in Euphorbia L. - I. Bangladesh J. Plant Taxon. 20(1): 27-38.

Dilcher, D.L. 1974. Approaches to the identification of angiosperm leaf remains. Bot. Rev. 40: 1-157.

Fontenelle, G.B., Costa, C.G. and Machado. R.D. 1994. Foliar anatomy and micromorphology of eleven species of Eugenia L. (Myrtaceae). Bot. J. Linn. Soc. 116: 111-133.

Irwin, H.S. and Turner, B.L. 1960. Chromosomal relationships and taxonomic considerations in the genus Cassia. Am. J. Bot. 47: 309-318.

Irwin, H.S. and Barneby, R.C. 1981. Tribe 2. Cassiae Bronn (1822). In: Pohlhill, R.M. and Raven, P.H. (Eds), Advances in Legume Systematics, Part 1. Royal Botanic Gardens, Kew, UK, pp. 97-106.

Irwin, H.S. and Barneby, R.C. 1982. The American Cassiinae. Memoir. New York Bot. Gard. 35: 1-918. 
Kotresha, K. and Seetharam, Y.N. 1995. Epidermal studies in some species of Bauhinia L. (Caesalpinioideae). Phytomorphology 45(1\&2): 127-137.

Kotresha, K. and Seetharam, Y.N. 2000. Epidermal micromorphology of some Cassia L. (Caesalpiniaceae). Phytomorphology 50(3\&4): 229-237.

Lersten, N.R. and Curtis, J.D. 1992. Foliar anatomy of Polygonum (Polygonaceae): Survey of epidermal and selected internal structures. Plant Syst. Evol. 182(1-2): 71-106.

Marazzi, B., Endress, K.P., de Queiroz, L.P.and Conti, E. 2006. Phylogenetic relationships within Senna (Leguminosae, Cassiinae) based on three chloroplast DNA regions: Patterns in the evolution of floral symmetry and extrafloral nectaries. Am. J. Bot. 93(2): 288-303.

Metcalfe, C.R. and Chalk, L. 1950. Anatomy of the Dicotyledons, Vol. 2. Oxford, pp. 1014-1024.

Metcalfe, C.R. 1968. Current development in systematic plant anatomy. In: Heywood, V.H. (Ed.), Modern Methods in Plant Taxonomy. Academic Press, London, New York, pp. 45-57.

Metcalfe, C.R. and Chalk, L. 1979. Anatomy of the Dicotyledons, Second edition, Vol. 1. Clarendon Press, pp. 63-75.

Naik, V.N. and Nirgude, S.M. 1981. Anatomy in relation to taxonomy of Chlorophytum (Liliaceae). Indian J. Bot. 4(2): 48-60.

Ogundipe, O.T., Kadiri, A.B. and Adekanmbi, O.H. 2009. Foliar epidermal morphology of some Nigerian species of Senna (Caesalpiniaceae). Indian J. Sci. \& Tech. 2(10): 5-9.

Rahman, M.O., Rahman, M.Z. and Begum, A. 2013. Numerical taxonomy of the genus Senna Mill. from Bangladesh. Bangladesh J. Plant Taxon. 20(1): 77-83.

Rejdali, M. 1991. Leaf micromorphology and taxonomy of North African species of Sideritis L. (Lamiaceae). Bot. J. Linn. Soc. 107: 67-77.

Saheed, S.A. and Illoh, H.C. 2010. A taxonomic study of some species in Cassiinae (Leguminosae) using leaf epidermal characters. Not. Bot. Hort. Agrobot. Cluj 38(1): 21-27.

Shaheen, N., Ajab, M., Hayat, M.Q. and Yasmin, G. 2009. Diversity of foliar trichomes and their systematic relevance in the genus Hibiscus (Malvaceae). Int. J. Agric. Biol. 11: 279-284.

Singh, V. 2001. Monograph on Indian subtribe Cassiinae (Caesalpiniaceae). Scientific Editions, Jodhpur, India.

Stace, C.A. 1965. Cuticular studies as an aid to plant taxonomy. Bull. Br. Mus. Nat. Hist. 4: 1-78.

Stace, C.A. 1984. The taxonomic importance of the leaf surface. In: Heywood, V.H. and Moore, D.M. (Eds), Current Concepts in Plant Taxonomy. Academic Press, London, pp. 67-94.

Tomblinson, P.B. 1961. Anatomical approach to the classification of the Musaceae. Bot. J. Linn. Soc. 55: 779-809.

Tschan, G.F. and Denk, T. 2012. Trichome types, foliar indumentum and epicuticular wax in the Mediterranean gall oaks, Quercus subsection Galliferae (Fagaceae): implications for taxonomy, ecology and evolution. Bot. J. Linn. Soc. 169: 611-644.

Yasmin, G., Khan, M.A., Shaheen, N. and Hayat, M.Q. 2010. Micromorphological investigation of foliar anatomy of Fagopyrum Mill. and Rumex L. of Polygonaceae. Pak. J. Bot. 42(1): 47-57. 